6. Спивак Л. И., Спивак Д. Л. Изменённые состояния сознания: типология, семиотика, психофизиология. Сознание $u$ физическая реальность. 1996. Т. 1, N 4. С. 48-55.

7. Тлостанова М. В. Транскультурация как модель социокультурной динамики. Вопросы социальной теории. 2011. Том V. С. 126-149.

8. Толкачев С. П. Гибридная образность в русской и английской постколониальной литературе. Филология и культура. 2017. № 2(48). C 193-200.

9. Черниговская Т. В. Чеширская улыбка кота Шредингера: язык и сознание. М., 2013. 448 с.

10. Эпштейн М. Н. Проективный словарь гуманитарных наук. M., 2017. $616 \mathrm{c}$.

11. Grof S., Grof Ch. Beyond Death: The Gates of Consciousness. L., $1980.96 \mathrm{p}$.

12. Ludwig A. M. Altered States of Consciousness. Archives of General Psychiatry. 1966. Vol. 15 (3). P. 225-234.

DOI https://doi.org/10.30525/978-9934-26-073-5-1-68

\title{
THE FUNCTION OF ANTINOMIES IN LANGUAGE
}

\author{
Prykhodchenko O. O. \\ Candidate of Philological Sciences, \\ Senior Lecturer at the Chair of Foreign Languages for Special Purposes \\ Zaporizhzhia National University \\ Zaporizhzhia, Ukraine
}

The main role of the person in the process of creation and development of the language system finds its representation in its inner laws. The dialectical nature of the development of the given structure made the principle of antinomisity one of its main axioms. This question was raised long ago, and now not only philosophers but also linguists are interested in this question. The study of such antinomies as «good - evil», «war - peace», «own - alien», «life - death» and others has a very important impact on the modern linguistics.

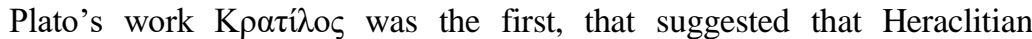
(objectivistic and onthologistic) and sophistic (subjectivistic and relativistic) visions of language are not only contrary to each other, but also complementary. But, this idea was too radical and innovatory for the time (and 
still, nowadays, there is the 'monologistic' majority of philosophy of language, who doesn't except this point of view) and European thought chose the less ambiguous and more logically formalistic Aristotelian framework, the basis of Cartesian rationalistic paradigm. Here, the dialogical 'antinomistic' interpretation of object cannot be accepted, as they understand the object according to the Principle of identity $(\mathrm{A}=\mathrm{A})$. Some occasional antinomistic treatments of the being and its constituent elements (language being one of them) can be found in Pascal's and Kant's works but they remained outside the general framework of the European thought.

Antinomies in language are the opposition of language units, facts, principles and relations. The first scientist, who developed Plato's ideas was Wilchelm von Humboldt. He admitted the double nature of language. Everything in language is alive. The language is created by the man in everyday life, in speech acts and helps in the process of communication. Communication is the only real state in which language exists. Language and real life can't exist separately. From the other hand, the language has the fundamental character. Vocabulary and grammar are given to an individual as something ready-made and unchangeable. We can use a language but we do not create it. Languages belong to nations, not to individuals. Language has its own life independent of an individual, its user, has its own power which is exercised upon us. This idea has had a great impact upon modern linguistics, but, still, there are some mainstreams, that remain monological.

Later there existed groups of scientists, that developed Platoe's and Humboldt's ideas. Despite the fact, that they worked alone they had a lot of similar ideas. Their main concepts are antinomy and dialogue. These two concepts were also present among the basic ideas of W. von Humboldt's works (though he did not use these terms).

In his principal philosophical work Ueber die Verschiedenheit des menschlichen Sprachbaues (On the Difference of Human Languages Structure) Humboldt argues that the two visions of language regarding it as either independent of a human soul or depending on it, in reality coincide and express the special character of the essence of language [2]. Language cannot be presented as being foreign to the soul and independent of it in its certain parts, and in some other parts utterly belonging to it. Language can be presented as a structure with many layers. When we speak, we use only some its layers, and other are unknown to us, but still, we treat them as a whole, with which it has a regular connection and inner harmony.

As, all, what man does is connected with his mental concepts, his relations with the objective world are greatly affected by language. And mental development of people is possible only with the help of language. Language as 
a whole is given to everybody, which means that every man aims at, regulated, stimulated and restricted by a certain force, exercising the verbal activity in accordance with his external or internal needs, and in such a way that could be understood by others [1, c. 35].

In modern linguistics, there exist some well-known antinomies such as «synchronic - diachronic», «statics - dynamics», «pragmatics syntagmatics», «inner and outer relations of the language», «language speech» and others. All these antinomies deal with the language from different points of view: from the historical development to the present days status, due to one of its main factors - the change of the language, due to associative and linear character of the language and of course the difference between the language as the system, which is developing constantly and the speech as its practical realization, its usage in the process of communication.

So, antinomies play the very important role in the developing of language. Due to its existence, the language can change. The exact quantity of antimonies in language is impossible to find, but all of them make the language flexible and live, the help the language to move.

\title{
References:
}

1. Гумбольдт В. фон Язык и философия культуры. М.: Прогресс, 1985. $452 \mathrm{c}$.

2. Yeremeyev Y. Language. Antinomy. Dialogue http://cogprints.soton.ac.uk/language / philosophy of language, Southampton, $2001 / /$ antinomy.narod.ru, 2001.

DOI https://doi.org/10.30525/978-9934-26-073-5-1-69

\section{INNER ASSOCIATION POWER BETWEEN ELEMENTS OF A BINOMIAL SEQUENCE}

\author{
Rizhok I. I. \\ Student \\ Ivan Franko National University of Lviv \\ Lviv, Ukraine
}

Binomials, generally defined as coordinated pairs of linguistic units that share partial semantic relations between their constituent components, are one of the most heterogeneous, and therefore, convoluted phenomena existing in the English language. In spite of the fact that they are extremely frequently 